\title{
Evolution of neonatal mortality by preventable causes over the past ten years in Espírito Santo State
}

\author{
Glícia Chierici Baptista 1
}

iD https://orcid.org/0000-0003-3496-5217

Wanêssa Lacerda Poton 2

iD https://orcid.org/0000-0001-5849-0653 1,2 Departamento de Medicina. Universidade de Vila Velha. Av. Comissário José Dantas de Melo, 21. Boa Vista. Vila Velha, ES, Brasil. CEP: 29.102-920.
E-mail: gliciachierici@hotmail.com

\begin{abstract}
Objectives: analyze neonatal mortality causes, highlighting the preventable ones from 2008 to 2017, in Espirito Santo State and health regions.

Methods: ecological study of temporal series on neonatal mortality using data from Mortality Information System and from Live Birth Information System. The death causes were classified based on the List of Avoidable Causes of Deaths due to Interventions of the Brazilian Health System. The temporal tendency was analyzed using linear regression.

Results: the neonatal mortality rate reduced, approximately 5\%, with a reduction of almost $27 \%$ in the late neonatal component. Approximately, $70 \%$ of neonatal deaths were preventable, with a higher frequency of reducible causes by adequate care at pregnancy, childbirth and to the newborn. The reduction was significant for adequate care for pregnant women in Espirito Santo and in Metropolitan Region and due to adequate care to the newborn in the South Region.

Conclusions: the main causes of neonatal deaths were due inadequate care for women during pregnancy, at childbirth and to the newborn, despite the reduction in neonatal mortality over the past 10 years. This study may contribute to the planning of health policies to improve care for pregnant women, parturient and to the newborn.
\end{abstract}

Key words Infant mortality, Child's health, Health status index

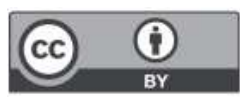




\section{Introduction}

Neonatal death is defined as the death of a newborn between zero and twenty-seven days after birth ${ }^{1}$ and it is a component of infant mortality. ${ }^{1}$ The neonatal mortality includes the early neonatal component, which represents deaths before completing 7 days of life, and the late neonatal component, which represents the death of a newborn between 7 and 27 days of life. 1

Brazilian neonatal mortality rate in 2017 consisted of 9 neonatal deaths per 1,000 live births a reduction of almost $15 \%$ when compared to 2008 , when it was 10 neonatal deaths per 1,000 live births. ${ }^{2}$ Even with this reduction, currently, the neonatal component represents about $70 \%$ of infant mortality, with an elevated participation of reducible death causes by adequate care for women during pregnancy and childbirth and to the newborn, 1,3 and, in most cases, they could be preventable by qualified healthcare.4,5 Potentially preventable death causes were considered as a sensitive indicator of the quality of healthcare and a useful instrument to evaluate the population's access to the service and the failures in the health system.3,6 It is also an indicator of socioeconomic conditions of a delimited territory, ${ }^{6}$ thus, it is important to elaborate public policies to reduce social inequalities.

In Espírito Santo (ES), the neonatal mortality rate has been decreasing - there was a decline of almost $24 \%$ between 2008 and 2017.2 Despite this reduction, in 2017, there were 11 infant deaths per 1,000 live births, and neonatal mortality represented 8 neonatal deaths per 1,000 live births, with a higher rate for early neonatal mortality $(6 / 1000){ }^{2}$ Considering that neonatal death includes early and late neonatal period, the data lead to a reflection on prenatal care, healthcare in the maternity and the newborn's first weeks of life. 7

As such, the neonatal mortality is the major component of infant mortality nowadays and knowing the preventable causes of this index is useful to guide the health policies, in order to reach a better health support for pregnant women, childbirth care and to the newborn.3,4 In addition, it is known that Brazilian neonatal mortality rate is irregularly distributed regionally, with the largest discrepancy between the North/Northeast and South/ Southeast regions, ${ }^{8}$ so, this research also analyzes regional differences in the distribution of this rate in the state of Espírito Santo. The study aims to analyze the causes of neonatal mortality and its components, highlighting the preventable causes, from 2008 to 2017, in Espírito Santo and health regions.

\section{Methods}

It was an ecological and retrospective study, about the causes of deaths of children between 0 and 27days-old, highlighting preventable death causes between 2008 and 2017 in Espírito Santo State and its health regions (North, Central, Metropolitan and South).

The analyzed variables were neonatal mortality and early and late neonatal components. The secondary data was obtained from Sistema de Informação de Mortalidade (SIM) (Mortality Information System) and Sistema de Informação de Nascidos Vivos (SINASC) (Live Birth Information System) from the Informática do Sistema Único de Saúde (DATASUS) (Public Health System Informatics Department). The infant deaths were classified based on the List of Avoidable Causes of Deaths due to the interventions of the Brazilian Public Health System, updated by Malta and collaborators in 2010,9 and they were grouped according to the basic cause, as it is in the International Classification of Diseases 10 (ICD-10).

The death causes were classified in three groups: (1) preventable causes; (2) deaths for ill-defined causes (3) other causes - not clearly preventable (NC-preventable). The preventable causes are divided in four big groups: (1) reducible by adequate care for women during pregnancy and childbirth and to the newborn; (2) reducible by adequate diagnosis and treatment actions; (3) reducible by immunization (4) reducible by adequate health promotion actions, associated to adequate healthcare actions. ${ }^{9}$

The group of reducible death causes by adequate care for women during pregnancy and childbirth and to the newborn is subdivided in three subsets of causes: (1) reducible by adequate care for women during pregnancy; (2) reducible by adequate care for women at childbirth; (3) reducible by adequate care to the newborn. 9

The neonatal mortality coefficient was calculated by using the numerator, the number of deaths of children until 27-days-old by place of residence, and in the denominator, the number of live births by place of residence for each year, multiplied for one thousand. ${ }^{1}$ In early neonatal mortality, the numerator was the children until 6-days-old and, in late neonatal mortality, the numerator was the children between 7 and 27-days-old. 1 In both components, the denominator was the number of live births by place of residence for each year, multiplied for one thousand.

In the descriptive analysis, it was presented the proportional mortality of preventable, NC- 
preventable and ill-defined causes in neonatal, early neonatal and late neonatal periods. The proportional mortality was calculated for each year using in the numerator, the number of neonatal, early neonatal and late neonatal deaths for each cause and in the denominator, the total number of neonatal, early neonatal and late neonatal deaths, multiplied by one hundred. ${ }^{1}$ Linear regression was used to analyze the temporal trend of neonatal mortality for preventable causes. The Breusch Godfrey test was applied to evaluate the correlation between the standard errors over the past years, showing whether it was necessary to correct them, and when the correlation between the standard errors was present, the PraisWinsten regression was used. The analysis was made by using the Stata program version 13.0.

The data used in this study is part of the public domain, with no nominal identification, under ethical principles in research involving humans, with no need of informed consent form. Moreover, this project was submitted and approved by the Ethical in Research with Humans Committee at the Universidade Vila Velha (CEP-UVV) (CAAE number: 92096218.9.0000.5064, report number: 2.764.676).

\section{Results}

Table 1 represents the rate and proportional mortality for causes in neonatal, early and late neonatal periods in Espírito Santo between 2008 and 2017. The late neonatal mortality rate presented a decrease of 3 per 1,000 births in 2008 and 2 per 1,000 births in 2017 -, however the same trend was not observed for the neonatal and early neonatal mortality. In all mortality rates (neonatal, early and late neonatal) there was a reduction in the proportion of preventable causes from 2008 to 2017 and an increase in the proportion of NC-preventable causes. This reduction and increase were more expressive in late neonatal mortality - $14 \%$ for preventable and $47 \%$ for NC-preventable causes, respectively.

\section{Espírito Santo State}

There was a discreet decline in preventable causes in early neonatal mortality in Espírito Santo State and an increase in late neonatal mortality after 2010, followed by a decrease after 2014 (Figure 1). This tendency was not statistically significant (Table 2).

Regarding the causes of neonatal mortality, the adequate care for women during pregnancy was the first cause in early and late neonatal mortality, however, this pattern had modified in late neonatal component in 2017 , when the reducible causes by adequate care to the newborn became the first one and the reducible causes by adequate care for women at childbirth was in third place (Figure 2). In early neonatal mortality, the second reducible cause was by adequate care for women at childbirth, followed by the reducible adequate care to the newborn (Figure 2). The decreased trend in reducible deaths by adequate care for women during pregnancy was $0.15(\mathrm{CI} 95 \%=-0.26 ;-0.05)$, on average, per year (Table 3).

\section{North Region}

The early neonatal mortality had discreetly decreased for preventable causes and had a linear tendency for NC-preventable. There was an increase in late neonatal mortality after 2010 , followed by a decrease after 2014 and an increase again in 2016

\section{Table 1}

Rate and proportional mortality in neonatal, early and late neonatal periods for preventable, not clearly preventable (NC-preventable) and ill-defined causes, Espírito Santo, 2008-2017.

\begin{tabular}{|c|c|c|c|c|c|c|c|c|c|c|}
\hline Causes & 2008 & 2009 & 2010 & 2011 & 2012 & 2013 & 2014 & 2015 & 2016 & 2017 \\
\hline Neonatal Mortality*(\%o) & 8.1 & 8.3 & 8.5 & 8.4 & 7.8 & 7.5 & 8.3 & 7.8 & 8.0 & 7.7 \\
\hline Preventable** & 75.4 & 71.1 & 71.7 & 71.4 & 74.8 & 76.4 & 71.0 & 69.3 & 72.7 & 70.9 \\
\hline NC-preventable** & 23.8 & 27.3 & 26.7 & 28.4 & 24.4 & 22.3 & 28.6 & 29.4 & 26.9 & 27.9 \\
\hline III-defined** & 0.8 & 1.6 & 1.6 & 0.2 & 0.8 & 1.3 & 0.4 & 1.3 & 0.4 & 1.2 \\
\hline Early Neonatal Mortality* & 7.5 & 5.6 & 6.0 & 6.2 & 5.5 & 5.0 & 6.1 & 5.7 & 5.8 & 5.8 \\
\hline Preventable** & 74.4 & 72.0 & 73.5 & 72.0 & 71.8 & 74.2 & 74.2 & 72.2 & 73.6 & 72.1 \\
\hline NC-preventable** & 24.8 & 26.3 & 24.6 & 28.0 & 27.5 & 24.7 & 25.2 & 26.6 & 26.0 & 27.0 \\
\hline III-defined** & 0.8 & 1.7 & 1.9 & 0.0 & 0.7 & 1.1 & 0.6 & 1.2 & 0.4 & 0.9 \\
\hline Late Neonatal Mortality* & 2.6 & 2.6 & 2.4 & 2.3 & 2.3 & 2.5 & 2.2 & 2.1 & 2.2 & 1.9 \\
\hline Preventable** & 78.3 & 69.1 & 67.5 & 70.0 & 82.0 & 80.9 & 62.1 & 61.0 & 70.1 & 67.3 \\
\hline NC-preventable** & 20.9 & 29.4 & 31.7 & 29.2 & 17.2 & 17.6 & 37.9 & 37.3 & 29.1 & 30.8 \\
\hline III-defined** & 0.8 & 1.5 & 0.8 & 0.8 & 0.8 & 1.5 & 0.0 & 1.7 & 0.8 & 1.9 \\
\hline
\end{tabular}

* Mortality rate; **Proportional mortality. 


\section{Figure 1}

Trend of early (A) and late (B) neonatal mortality for all mortality causes, Espírito Santo and health regions, 2008-2017.
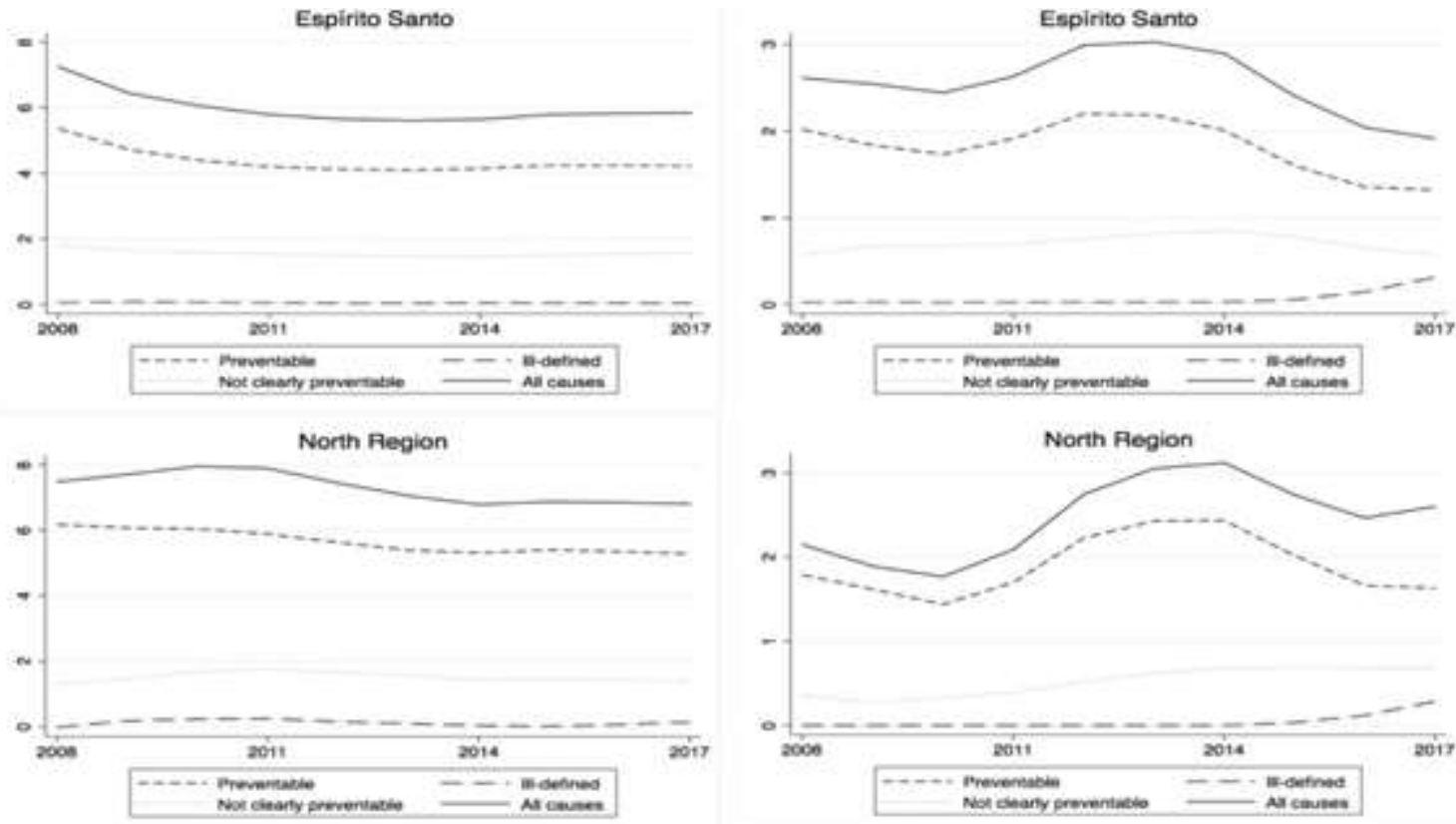

Contral Region
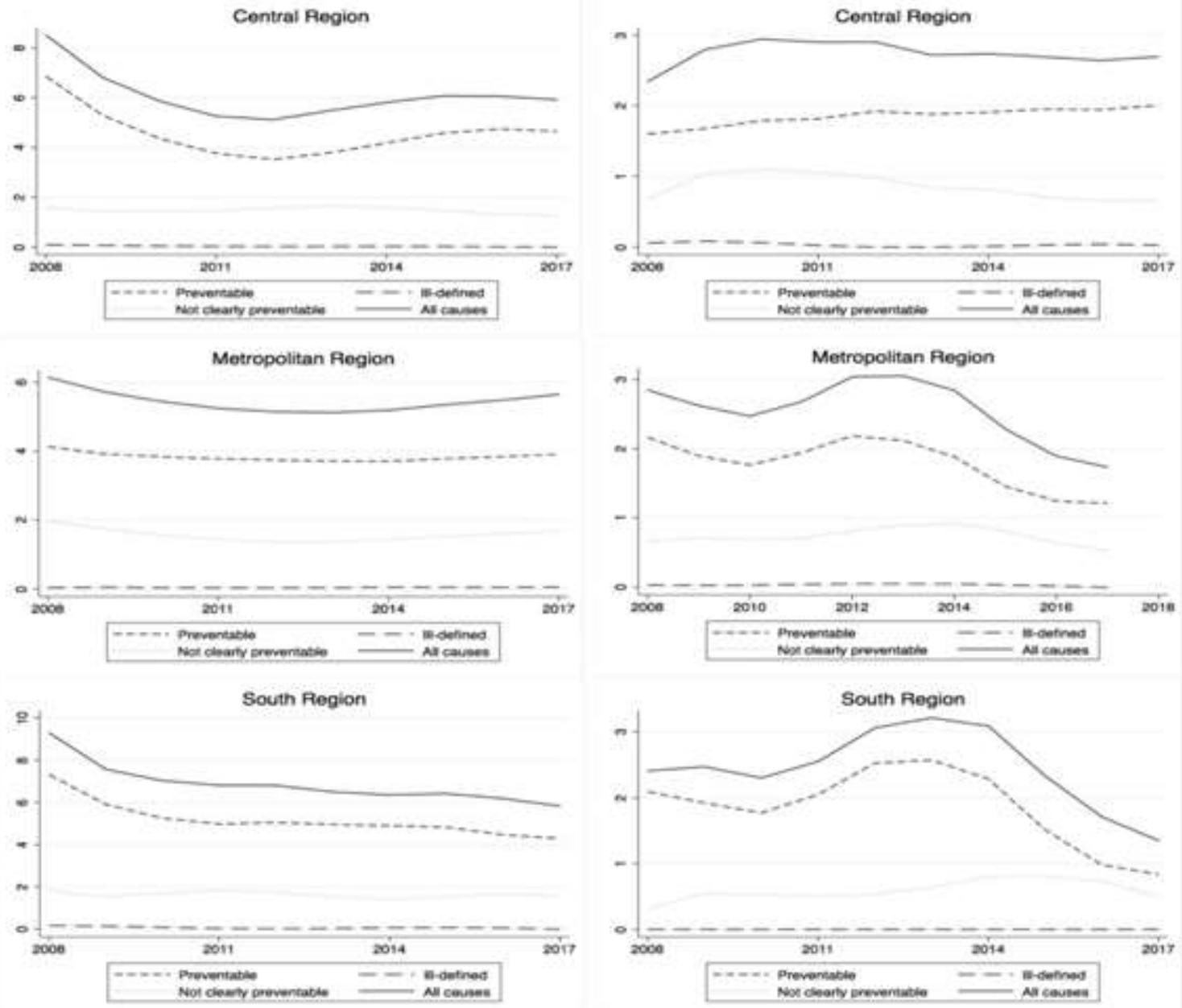

A 
Table 2

Regression coefficient of neonatal mortality rate for preventable, NC-preventable and ill-defined causes, Espírito Santo and health regions, 2008-2017.

\begin{tabular}{|c|c|c|c|c|c|}
\hline Causes & North & Central & Metropolitan & South & Espírito Santo \\
\hline Preventable & $-0.01(-0.17 ; 0.17)$ & $0.04(-0.23 ; 0.30)$ & $-0.01(-0.13 ; 0.13)$ & $-0.24(-0.45 ;-0.04)$ & $-0.04(-0.09 ; 0.01)$ \\
\hline NC-preventable & $0.06(-0.07 ; 0.20)$ & $-0.03(-0.16 ; 0.09)$ & $0.01(-0.06 ; 0.07)$ & $0.03(-0.11 ; 0.18)$ & $0.01(-0.05 ; 0.07)$ \\
\hline III-defined & $-0.10(-0.24 ; 0.03)$ & $-0.10(-0.21 ; 0.01)$ & $-0.12(-0.27 ; 0.04)$ & $-0.12(-0.27 ; 0.03)$ & $-0.11(-0.26 ; 0.03)$ \\
\hline
\end{tabular}

Table 3

\begin{tabular}{|c|c|c|c|c|c|c|}
\hline \multirow[t]{2}{*}{ Health regions } & $\begin{array}{c}\text { Care for } \\
\text { pregnancy }\end{array}$ & $\begin{array}{l}\text { Care for } \\
\text { childbirth }\end{array}$ & $\begin{array}{l}\text { Care to } \\
\text { newborn }\end{array}$ & $\begin{array}{c}\text { Diagnosis and } \\
\text { treatment }\end{array}$ & Immunization & $\begin{array}{l}\text { Health } \\
\text { promotion }\end{array}$ \\
\hline & \multicolumn{6}{|c|}{$\beta(C 195 \%)$} \\
\hline North & $-0.15(-0.36 ; 0.07)$ & $-0.04(-0.19 ; 0.10)$ & $0.04(-0.12 ; 0.20)$ & $-0.05(-0.13 ; 0.04)$ & * & $0.01(-0.03 ; 0.06)$ \\
\hline Central & $-0.08(-0.37 ; 0.21)$ & $-0.08(-0.19 ; 0.03)$ & $0.07(-0.09 ; 0.23)$ & $-0.03(-0.08 ; 0.02)$ & * & $-0.01(-0.01 ; 0.01)$ \\
\hline Metropolitan & $-0.19(-0.27 ;-0.11)$ & $-0.02(-0.11 ; 0.06)$ & $0.03(-0.01 ; 0.07)$ & $-0.03(-0.08 ; 0.02)$ & * & $0.01(-0.01 ; 0.01)$ \\
\hline South & $-0.08(-0.32 ; 0.16)$ & $-0.05(-0.12 ; 0.01)$ & $-0.20(-0.31 ;-0.10)$ & $-0.06(-0.13 ; 0.01)$ & * & $-0.01(-0.04 ; 0.02)$ \\
\hline Espírito Santo & $-0.15(-0.26 ;-0.05)$ & $-0.04(-0.11 ; 0.03)$ & $-0.01(-0.06 ; 0.05)$ & $-0.04(-0.10 ; 0.02)$ & * & $0.01(-0.01 ; 0.01)$ \\
\hline
\end{tabular}

$\beta$ : regression coefficient; *No data available in this period.

and 2017. This same pattern occurred in mortality for preventable causes (Figure 1). This tendency was not statistically significant (Table 2).

In the early neonatal mortality, reducible causes by adequate care for women during pregnancy decreased, but it still represented the first cause in 2017. Differently, the causes related to adequate care to the newborn and to women at childbirth showed an increasing trend in the last three years. In the late neonatal component, the reducible causes by adequate care to the newborn were the first cause, with a decreasing trend. The second cause were the reducible causes by adequate care for women during pregnancy, which increased between 2010 and 2014 - reaching the first place during this period - and then declined. In 2008, the reducible causes by adequate health promotion actions were the third cause, but after 2010, the reducible causes by adequate care for women at childbirth took the position (figure 2). These trends of neonatal mortality were not statistically significant (Table 3 ).

\section{Central Region}

The early neonatal mortality by preventable causes decreased between 2008 and 2012 and then had a discreet raise until 2017; the NC-preventable and ill-defined causes stood stable during the analyzed period. The late neonatal mortality increased between 2008 and 2010, followed by a slight decrease between 2011 and 2017. The preventable causes trend showed a continuous increase during these years and the NC-preventable started to reduce after 2009 (Figure 1). These tendencies were not statistically significant (Table 2).

In early neonatal mortality, the main cause was the reducible by adequate care for women during pregnancy, but this pattern changed in 2017 when the reducible causes by adequate care to the newborn reached first place. The third place was occupied by the reducible causes by adequate care for women at childbirth over the analyzed years. In the late neonatal component, the major reducible cause was by adequate care to the newborn and showed a growth tendency after 2014 . The reducible causes by adequate care for women during pregnancy stood in second place, with a slight decreased tendency from 2015. The reducible causes by adequate care for women at childbirth were the third cause, however, the reducible causes by adequate diagnosis and treatment actions were in third place in 2017 (Figure 2). These results were not statistically significant (Table $3)$. 
Figure 2

Trend of early (A) and late (B) neonatal mortality for preventable causes, Espírito Santo and health regions, 2008-2017.
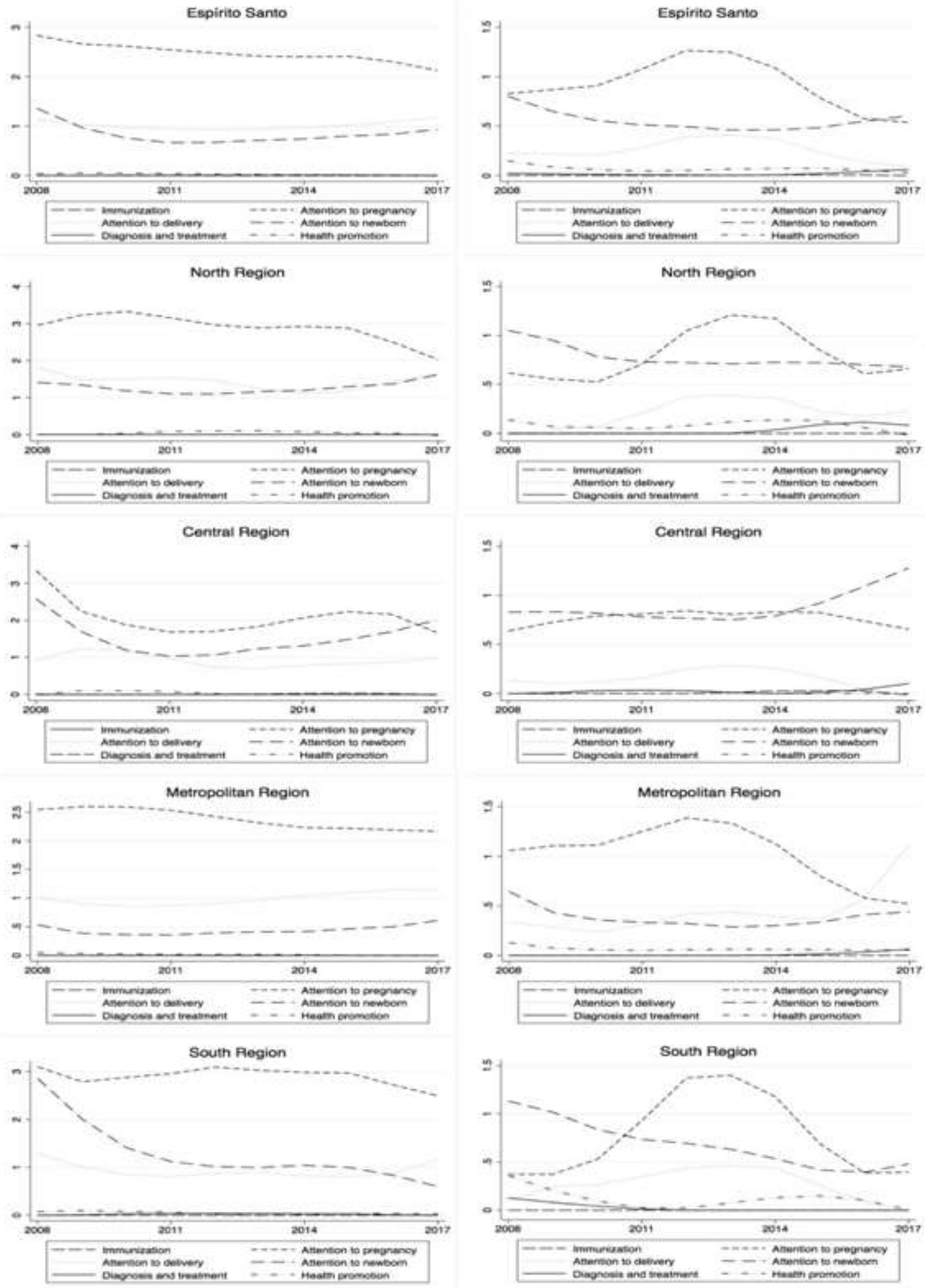

A 


\section{Metropolitan Region}

There was a slight decline in early neonatal mortality between 2008 and 2014, maintaining an increased tendency until 2017. The cause responsible for this pattern was NC-preventable. Preventable causes have maintained a linear trend during the analyzed period. There was an increase in late neonatal mortality after 2010 , followed by a decrease after 2014. This pattern was more relevant in mortality for preventable causes (Figure 1). These trends were not statistically significant (Table 2).

The first cause of early neonatal mortality was reducible by adequate care for women during pregnancy, followed by reducible causes by adequate care for women at childbirth and the reducible causes by adequate care to the newborn, with a continuous trend for these causes. In late neonatal mortality, in 2008, the major causes were the reducible causes by adequate care for women during pregnancy, the reducible causes by adequate care to the newborn and the reducible causes by adequate care for women at childbirth, respectively. This pattern changed substantially in 2017, when the first cause was reducible by adequate care for women at childbirth, the second reducible cause was by adequate care for women during pregnancy and the third one was the reducible causes by adequate care to the newborn (Figure 2). Every year there was a decrease, an average of $0.19(\mathrm{CI} 95 \%=-0.27 ;-0.11)$ in neonatal mortality rate due to reducible causes by adequate care for women during pregnancy (Table $3)$.

\section{South Region}

In the early neonatal mortality, there was a reduction during the analyzed period and this decrease occurred in preventable causes. This pattern was not the same for the late neonatal mortality, which had an increase after 2010, followed by a decrease after 2014. This was more relevant in mortality for preventable causes (Figure 1). This decreased tendency in the neonatal mortality rate for preventable causes was, an average of 0.24 $(\mathrm{CI} 95 \%=-0.45 ;-0.04)$ per year (Table 2$)$.

The first early neonatal mortality cause was reducible by adequate care for women during pregnancy, which showed a continuous trend. The second cause in 2008 was a reducible one by adequate care to the newborn, but it presented an important decrease and, in 2017, it represented the third cause. The reducible causes by adequate care for women at childbirth showed a continuous trend, and it was the second cause in 2017. In the late neonatal mortality, the reducible causes by adequate care to the newborn were the major cause until 2010 and kept falling until 2017. The reducible causes by adequate care for women during pregnancy stood in second place and showed a growth tendency between 2010 and 2014 - when it represented the first cause - followed by a decline. The third cause was a reducible one by adequate health promotion actions, which had a decreasing trend. The reducible causes by adequate care for women at childbirth showed an increasing trend between 2008 and 2014, followed by a decline and it represented the fourth cause in 2017 (Figure 2). The main reduction in neonatal mortality was due to adequate care for the newborn, which showed a decrease, an average of $0.20(\mathrm{CI} 95 \%=-0.31 ;-0.10)$ in the neonatal mortality rate from preventable causes per year (Table 3 ).

\section{Discussion}

In Espírito Santo, there was a decreasing trend in neonatal mortality for preventable causes, although, they still represented about $71 \%$ of neonatal mortality causes in 2017 . The reduction was greater in the late neonatal component, in which the preventable causes represented approximately $67 \%$ in 2017, with an important participation of reducible causes by adequate care for women during pregnancy and at childbirth and to the newborn. In Espírito Santo and the Metropolitan region, the reduction was significant due to adequate care for women during pregnancy and due to adequate care to the newborn in the South region. This pattern is similar to what is shown in other Brazilian States, 10 13 in Brazil ${ }^{1}$ and in Argentina, which presented 68\% of the neonatal deaths due to disorders in perinatal period, including newborns affected by complications related to pregnancy, labor and childbirth. 14

It is known that preventable death causes reflect the quality of health services and the social inequalities, 3,6 therefore, there are differences in the neonatal mortality causes in developed countries, such as in Australia, that presented an important participation of NC-preventable causes, as congenital anomalies $(28 \%)$ and neurological conditions (11\%) in neonatal mortality. 15 While in developing countries, such as Pakistan, there was an increase in neonatal mortality related to ineffective newborn care between 1991 and 2013.16 Furthermore, a study developed in a tertiary public healthcare facility in the same country showed that infectious diseases were the leading neonatal mortality cause, including respiratory distress syndrome (24\%) and sepsis (18\%).17 In Ethiopia, prematurity, asphyxia and infections were also the main causes of neonatal deaths. 18 
This study showed an increase in late neonatal mortality by preventable causes between 2010 and 2014 in Espírito Santo, especially for the reducible causes by adequate care for women during pregnancy. There was a reduction in health financing in the State in 2009 reflecting the international economic crisis occurred in 2008.19-21 Although, the official documents of the State revealed a continuous investment in primary care and an increase in maternal and infant care, due to the change in the paradigm of the hospital-centric system to the primary care model, which occurred in that period. ${ }^{19-21}$ Therefore, this pattern could not be justified by a lack of investment in infant and maternal health between 2008 and 2011.19-21 An ecological study developed in Pernambuco to evaluate the impact of prenatal, childbirth and newborn health care programs in neonatal mortality for preventable causes, showed a reduction in this index, not related to the creation of these programs, showing that there are other factors also influencing in preventable neonatal mortality, as the quality and availability of high complexity services, such as neonatal unit care, that represents a higher impact in neonatal mortality. 22

It was noticed that, in 2016, the smallest neonatal mortality rate was from the Metropolitan region of Espírito Santo, however, the prenatal coverage was higher for the North and Central regions in 2015.7 The proportion of live births of mothers with seven or more prenatal appointments was $72 \%$ in the North, $74 \%$ in the Central Region, $68 \%$ in the Metropolitan and $63 \%$ in the South region. ${ }^{7}$ In Pernambuco, there was also an increase in prenatal care coverage in the countryside regions and not related to a reduction in neonatal mortality by preventable causes. ${ }^{22}$ This result shows that is necessary not only to expand the prenatal coverage, but also to improve the quality of the care offered.

Furthermore, a national cohort study showed that prematurity and low birth weight were the main factors related to neonatal mortality 23 and it is known that prematurity may occur for iatrogenic reasons, such as cesarian section without technical indication. 3,23 The same research found that the cesarian section represented almost $57 \%$ of childbirths between 2011 and 2012 in the Country 23 and that almost $50 \%$ of the newborns under $1,500 \mathrm{~g}$ that were born in a hospital without neonatal intensive care, died, highlighting the importance of high complexity maternity hospitals. 23 In 2015 , there were $63 \%$ of cesarian sections in Espírito Santo, placing it at fourth in the country ranking. 7 The proportion of cesarian section in the same year for the regions, was $60 \%$ in the North, $64 \%$ in the Central, $61 \%$ in the Metropolitan and $70 \%$ in the South. 7 Therefore, these numbers show the importance to prevent the evitable prematurity by adequate prenatal care and reduction in over medicalization of childbirth. ${ }^{3}$ There is a paradox, which shows that the technology in health services may lead to a decrease in neonatal mortality or it may increase this index by promoting iatrogenic actions in childbirth care.6,24

Despite the considerations above, there was a reduction in neonatal mortality by preventable causes between 2008 and 2017 and important advances in maternal and infant care in the public health system occurred during this period. Between 2012 and 2013, the government adopted three important programs: the Rede Cegonha, which is a strategy to organize the maternal and infant healthcare in the Country, focused in a multi-professional team; the Rede Bem Nascer, which represented an important investment in low and high risk maternity hospitals in the four health regions; and Rede Materno Infantil, which focused in training the health professionals in breastfeeding skills, neonatal resuscitation and adequate care to preterm newborns. 25 In addition, the primary health care coverage in Espírito Santo increased almost 5\% between 2008 and 2017, reaching nearly $71 \%$ in 2017.26

There was an improvement in pediatric care in 2017 with the creation of another twenty-four-hour emergency center and the increase in hospital beds in infant hospitals in Metropolitan and South regions. ${ }^{26}$ In 2017, it was also created the Rede Cuidar, a strategy to organize healthcare that increased the capacity of hospitals to normal and high risk childbirth care in the North region. ${ }^{26}$ As the data about the following years is not available in the public domain yet, other studies are necessary to evaluate the impact of these new health politics in neonatal mortality.

Some positive points and limitations of this study should be highlighted. An important limitation was the use of secondary data, obtained from the information systems, so, it may occur underreporting. However, a document from the Sistema Nacional de Vigilância (National Surveillance System) showed that the ratio between the deaths reported to SIM and those estimated for the Instituto Brasileiro de Geografia e Estatística (IBGE) (Brazilian Institute of Geography and Statistics) in Espírito Santo was about 97\%in 2009, being above the average for Brazil.27 A study that evaluated the quality of SIM data in Espírito Santo between 2007 and 2009 demonstrated regular and bad complete- 
ness in filling the variables race/color, age and maternal schooling level, ${ }^{28}$ which does not compromise the results of this study, as this information was not used. A study developed in São Paulo identified good SIM usability and proper performance when evaluating 45 quality attributes, finding only 8 attributes with divergent or inconclusive results. ${ }^{29}$

Regarding the SINASC coverage, Espírito Santo presented a concordance of approximately $88 \%$ in recorded information in 2009, when compared to IBGE's estimative. 27 A study performed in Espírito Santo found that all the SINASC variables evaluated had an excellent completeness level, showing the potential of this system as source of information about births. 28 Another positive point is that, in Espírito Santo, there is a Comitê de Vigilância de Óbitos Maternos e Infantis (Maternal and Child Death Surveillance Committee), that investigates the infant and maternal deaths, ${ }^{7}$ and the work of this committee has substantially reduced the proportion of ill-defined causes of mortality.

Despite the reduction in neonatal mortality over the past 10 years, inadequate care for women during pregnancy, childbirth and to the newborn remain as the main causes of neonatal deaths. Therefore, this study may contribute to the planning of health policies to improve the services that provide care for pregnant women, childbirth and to the newborns.

\section{Acknowledgments}

This study was developed with the support of the Universidade Vila Velha, which provided financial support through the Iniciação Cientifica Institucional (Institutional Scientific Initiation) scholarship.

\section{Authors' contribution}

Baptista GC was responsible for collecting data, interpreting the results and writing this article. Poton WL was responsible for analyzing data, interpreting the results and making the critical review of this manuscript. The authors approved the final version of this article.

\section{References}

1. Brasil. Ministério da Saúde. Secretaria de Vigilância em saúde. Secretaria de atenção à Saúde. Manual de vigilância do óbito infantil e fetal e do comitê de prevenção do óbito infantil e fetal. 2 ed. Brasília, DF;2009.

2. Brasil. Ministério da Saúde. Departamento de Informática do SUS [Internet]. Informações de saúde. Estatísticas vitais Mortalidade e nascidos vivos. Brasília, DF: Ministério da Saúde. [acesso em 2 abr 2020]. Disponível em:http://www.datasus.gov.br/DATASUS/index.php?area= 0205

3. Victora CG, Aquino EML, Leal MC, Monteiro CA, Barros FC, Szwarcwald CL. Maternal and child health in Brazil: progress and challenges. Lancet. 2011; 377: 1863-76.

4. França EB, Lansky S, Rego MAS, Malta DC, França JS, Teixeira R, Porto D, de Almeida MF, de Souza MFM, Szwarcwald CL, Mooney M, Naghavi M, Vasconcelos AMN. Principais causas da mortalidade na infância no Brasil, em 1990 e 2015: estimativas do estudo de Carga Global de Doença. Rev Bras Epidemiol. 2017; 20 (Suppl. 1): $46-60$

5. França E, Lansky S. Mortalidade infantil neonatal no Brasil: situação, tendências e perspectivas. In: Anais do XVI Encontro Nacional de Estudos Populacionais; 22 - 28 set 2008; Poços de Caldas, MG. Poços de Caldas, MG: Associação Brasileira de Estudos Populacionais; 2008. Sessão temática 42. p. 1-29.
6. Dias BAS, Santos NET, Andrade MAC. Classificações de evitabilidade dos óbitos infantis: diferentes métodos, diferentes repercussões? Cad Saúde Pública. 2017; 33(5): $\mathrm{e} 00125916$.

7. Espírito Santo. Secretaria de Estado da Saúde.Resolução $\mathrm{N}^{\circ}$. 969/2016, de 29 de setembro de 2016. Plano Estadual de Saúde 2016-2019. Vitória, 2016. [acesso em 2 abr 2020]. Disponível em: https://saude.es.gov.br/Media/sesa/Planejamento/PES\%20$\% 20$ Plano $\% 20$ Estadual $\% 20$ de $\% 20$ Saude_2016-2019-1.pdf.

8. Veloso FCS, Kassar LML, Oliveira MJC, De Lima THB, Bueno NB, Gurgel RQ, KassarSB. Analysis of neonatal mortality risk factors in Brazil: a systematic review and meta-analysis of observational studies. J Pediatr (Rio J.). 2019; 95(5): 519-30.

9. Malta DC, Sardinha LMV, De Moura L, Lansky S, Leal MC, Szwarcwald CL, França E, De Almeida MF, DuarteEC. Atualização da lista de causas de mortes evitáveis por intervenções do Sistema Único de Saúde do Brasil. EpidemiolServSaúde. 2010;19(2): 173-6.

10. Gaiva MAM, Fujimori E; Sato APS. Mortalidade neonatal: análise das causas evitáveis. RevEnferm UERJ. 2015; 23(2):247-53

11. Ferrari RAP, Bertolozzi MR, Dalmas JC, Girotto E. Fatores determinantes da mortalidade neonatal em um município da Região Sul do Brasil. Rev Esc Enferm USP. 2013; 47 (3): $531-8$. 
12. Nascimento LFC, Almeida MCS, Gomes CMS. Causas evitáveis e mortalidade neonatal nas microrregiões do estado de São Paulo. Rev BrasGinecol Obstet. 2014; 36(7): 303-9.

13. Rocha R, Oliveira C, Da Silva DKF, Bonfim C. Mortalidade neonatal e evitabilidade: uma análise do perfil epidemiológico. Rev Enferm UERJ. 2011; 19(1):114-20.

14. Finkelstein JZ, Duhau M, Fasola ML, Escobar P. Neonatal mortality in Argentina. Situation analysis from 2005 to 2014. Arch Argent Pediatr. 2017;115(4):343-9.

15. Australia. Australian Government. Australian Institute of Health and Welfare.29 May 2018. Perinatal deaths in Australia 2013-2014. [acesso em4 jul2019]. Disponível em: https:/www.aihw.gov.au/getmedia/78784f2e-2f61-47ea9908-84b34441ae0a/aihw-per-94.pdf.aspx?inline=true.

16. Ahmed M, Won Y. Cross-National Systematic Review of Neonatal Mortality and Postnatal Newborn Care: Special Focus on Pakistan. Int J Environ Res Public Health. 2017;14(12): 1442 .

17. Mustufa MA, Korejo R, Shahid A, Nasim S. Infection remains a leading cause of neonatal mortality among infants delivered at a tertiary hospital in Karachi, Pakistan. J Infect DevCtries. 2014;8(11):1470-5.

18. Mengesha HG, Sahle BW. Cause of neonatal deaths in Northern Ethiopia: a prospective cohort study. BMC Public Health. 2017;17 (62).

19. Espírito Santo. Secretaria de Estado da Saúde do Espírito Santo. 2017 May 04. Prestação de Contas 2008 e 2009 - $4^{\circ}$ e $1^{\circ}$ trim. [acesso em 2 abr2020]. Disponível em: https://saude.es.gov.br/Media/sesa/Presta $\% \mathrm{C} 3 \% \mathrm{~A} 7 \% \mathrm{C} 3 \%$ A3o $\% 20 \mathrm{de} \% 20$ Contas/Prestacao $\% 20$ Contas $\% 204 \%$ C3 $\% 82$ $\% \mathrm{C} 2 \%$ BA $\% 20$ T. $\% 202008 \% 20 \mathrm{e} \% 201 \% \mathrm{C} 3 \% 82 \% \mathrm{C} 2 \%$ BA $\% 20$ T.\%202009.pdf

20. Espírito Santo. Secretaria de Estado da Saúde do Espírito Santo. 2017 May 04. Prestação de Contas $-3^{\circ}$ e $4^{\circ}$ Trimestres $2009 \mathrm{e}^{\circ}$ Trimestre 2010. [acesso em 2 abr 2020]. Disponível em: https://saude.es.gov.br/Media/ sesa/Presta $\%$ C3\%A7\%C3\%A3o\%20de\%20Contas/Prestaca o $\% 20$ Contas $\% 203 \%$ C3\%82\%C2\%BA $\% 20 \% 20 \mathrm{e} \% 20 \% 204$ $\%$ C3\%82\%C2\%BA\%20T.\%202009\%20e\%201\%С3\%82\% C2\%BA\%20T.\%202010.pdf

21. Espírito Santo. Secretaria de Estado da Saúde do Espírito Santo. 2017 May 04. Prestação de Contas - $2^{\circ}$ Semestre de 2011. [acesso em 2 abr 2020]. Disponível em https://saude.es.gov.br/Media/sesa/Presta\%C3\%A7\%C3\% A3o $\% 20 \mathrm{de} \% 20$ Contas/Prestacao $\% 20$ Contas $\% 202 \% \mathrm{C3} \% 82$ $\% \mathrm{C} 2 \%$ BA $\% 20$ Semestre $\% 20 \mathrm{de} \% 202011$.pdf
22. De Lima SS, Braga MC, Vanderlei LCM, Luna CF, Frias PG. Avaliação do impacto de programas de assistência prénatal, parto e ao recém-nascido nas mortes neonatais evitáveis em Pernambuco, Brasil: estudo de adequação. Cad Saúde Pública. 2020; 36(2): e00039719.

23. Lansky S, Friche AAL, Da Silva AAM, Campos D, Bittencourt SDA, De Carvalho ML, De Frias PG, Cavalcante RS, Da Cunha AJLA. Pesquisa Nascer no Brasil: perfil da mortalidade neonatal e avaliação da assistência à gestante e ao recém-nascido. Cad SaúdePública.2014; 30(Suppl. 1): S192-S207.

24. Diniz SG. Gênero, saúde materna e o paradoxo perinatal. RevBrasCresc Des Hum. 2009; 19(2):313-26.

25. Espírito Santo. Secretaria de Estado da Saúde do Espírito Santo. 2017 May 04. Prestação de Contas - $3^{\circ}$ Quadrimestre de 2013. [acesso em 2 abr 2020]. Disponível em: https://saude.es.gov.br/Media/sesa/Presta\%C3\%A7\%C3\% A3o $\% 20 \mathrm{de} \% 20 \mathrm{Contas} /$ Presta $\% \mathrm{C3} \% \mathrm{~A} 7 \% \mathrm{C3} \% \mathrm{~A} 3 \mathrm{o} \% 20 \mathrm{Con}$ tas\%203\%C2\%BA\%20Q.\%202013.pdf

26. Espírito Santo. Secretaria de Estado da Saúde do Espírito Santo. 2018 Mar 19. Prestação de Contas - $3^{\circ}$ Quadrimestre de 2017. [acesso em 2 abr 2020]. Disponível em: https://saude.es.gov.br/Media/sesa/Presta $\% \mathrm{C} 3 \% \mathrm{~A} 7 \% \mathrm{C} 3 \%$ A3o $\% 20 \mathrm{de} \% 20$ Contas/Ricardo_Presta $\% \mathrm{C} 3 \% \mathrm{~A} 7 \% \mathrm{C} 3 \% \mathrm{~A} 3$ o\%20de\%20Contas\%203\%C2\%BA\%20quad $\% 202017 \% 20$ _13_\%20preliminar.pdf

27. Brasil. Ministério da Saúde. Secretaria de Vigilância em Saúde. Sistema Nacional de Vigilância em Saúde: relatório de situação Espírito Santo. Brasília, DF; 2011. 5 ed. [acesso em 2 abr 2020]. Disponível em: http://bvsms.saude.gov.br/bvs/publicacoes/sistema naciona 1_vigilancia_saude_es_5ed.pdf.

28. Silva LP, Moreira CMM, Amorim MHC, Castro DS, Zandonade E. Avaliação da qualidade dos dados do Sistema de Informações sobre Nascidos Vivos e do Sistema de Informações sobre Mortalidade no período neonatal, Espírito Santo, Brasil, de 2007 a 2009. CiêncSaúdeColetiva. 2014; 19 (7): 2011-20

29. De Morais RM, Costa AL. Uma avaliação do Sistema de Informações sobre Mortalidade. Saúde Debate. 2017; 41(spe): 101-17.

Received on October 7, 2019

Final version presented on July 8, 2020

Approved on November 26, 2020 